\title{
Pemurnian Pretrombin-2 Manusia Rekombinan di Escherichia coli untuk Produksi Trombin sebagai Komponen Lem Fibrin
}

\section{Purification of Recombinant Human Prethrombin-2 in Escherichia coli for Thrombin Production as Fibrin Glue Components}

\author{
Saronom Silaban ${ }^{1 *}$; Iman Permana Maksum²; Khomaini Hasan ${ }^{3}$; Sutarya Enus ${ }^{4}$; Toto \\ Subroto $^{2}$; Soetijoso Soemitro ${ }^{2}$
}

1Jurusan Kimia, Fakultas MIPA, Universitas Negeri Medan, Medan-Indonesia

2Departemen Kimia, Fakultas MIPA, Universitas Padjadjaran, Bandung-Indonesia

${ }^{3}$ Pusat Penelitian Biosains dan Bioteknologi, Institut Teknologi Bandung, Bandung-Indonesia

${ }^{4}$ Pusat Mata Nasional, Rumah Sakit Mata Cicendo, Bandung-Indonesia

*Korespondensi: saronomsilaban@unimed.ac.id

\begin{abstract}
Abstrak: Pretrombin-2 (PT2) adalah precursor trombin yang berperan mengubah fibrinogen menjadi fibrin untuk proses penutupan luka. Bahan ini dapat diterapkan sebagai pengganti teknik jahitan bedah mata. Sistem pemurnian yang dimediasi intein untuk memurnikan protein menarik untuk dikembangkan, karena protein diperoleh dengan satu tahap pemurnian, mampu melakukan pemotongan sendiri (self-splicing), protein dapat difusikan pada (pemotongan PT2 dari penanda intein terinduksi pH dan suhu) dan pada C-terminal (pemotongan PT2 dari penanda intein terinduksi pereaksi tiol). Dalam studi ini, kami memurnikan fusi PT2 hasil ekspresi E. coli BL21(DE3) ArcticExpress dalam kolom matriks kitin yang dimediasi intein. PT2 difusikan dengan suatu tag pada posisi Nterminalnya, yang mengandung urutan pengode intein SspDnaB diikuti oleh domain pengikat kitin (CBD). Selanjutnya fusi PT2 diekspresikan pada inang E. coli, selanjutnya dimurnikan dalam kolom matriks kitin. Proses pemotongan PT2 dari penanda intein diinduksi perubahan $\mathrm{pH}$ dan suhu dalam kolom.Fusi PT2 berhasil dimurnikan dalam matriks kitin yang dimediasi intein. Pemotongan fusi PT2 dari penanda intein terinduksi buffer $\mathrm{pH}$ 6,5 dan suhu inkubasi $25^{\circ} \mathrm{C}$ selama 48 jam.
\end{abstract}

Kata kunci: E. coli, ekspresi, pemurnian dimediasi intein, perubahan pH dan suhu, PT2

\begin{abstract}
Pretrombin-2 (PT2) is a thrombin precursor that plays a role in converting fibrinogen to fibrin for the process of wound recovery. This material can be applied instead of eye surgery suture technique. The inteinmediated refining system to purify the protein is attractive to be developed, since the protein is obtained by one purification step, capable of self-splicing, the protein can be diffused in to the N-terminal (PT2 cutting of the intein induced marker changes in $\mathrm{pH}$ and temperature) and on the C-terminal (cutting PT2 from the intein-induced marker of the thiol reagent). In this study, we purified the PT2 fusion of the expression of E. coli BL21 (DE3) Arctic Express in the intein-mediated chitin matrix column. PT2 was fused with a tag at its N-terminal position, containing the sequence of intein codes SspDnaB followed by chitin binder domain (CBD). Furthermore, the PT 2 fusion was expressed on the E. coli host, then purified in the chitin matrix column. The PT2 cutting process of the intein marker induced changes in the $\mathrm{pH}$ and temperature in the column. PT2 fusion was successfully purified in the intein-mediated chitin matrix. The PT2 fusion cut from the induced intein buffer marker at $p H 6.5$ and incubation at the temperature of $25^{\circ} \mathrm{C}$ for 48 hours.
\end{abstract}

Keywords: E. coli, expression, intein mediated purification, $p H$ and temperature changes, PT2

\section{PENDAHULUAN}

Meningkatnya jumlah pasien yang menjalani operasi di berbagai Rumah Sakit di Indonesia saat ini, menjadi tantangan serius terhadap dunia kesehatan, terutama dalam upaya meminimalkan kerugian pelaksanaan operasi. Salah satu upaya yang perlu mendapat perhatian adalah mengembangkan teknik lain pengganti jahitan. Teknik jahitan merupakan standar emas untuk menutup luka. Namun penggunaannya menimbulkan kerugian, diantaranya waktu penyembuhan luka berlangsung lama, proses pembedahan lebih panjang, munculnya trauma tambahan bagi pasien saat pemasangan dan pencabutan benang, meningkatnya inflamasi, serta kemungkinan timbul komplikasi yang berhubungan dengan jahitan berupa infeksi (Uy et al., 2005; Enus dkk., 2011).

Lem Fibrin (LF) pengganti teknik jahitan memiliki kemampuan untuk merekatkan dan menutup luka. LF sebagai bahan bioadesif, tersusun atas trombin, fibrinogen, kalsium dan faktor XIII. Bahan ini dirancang untuk menyerupai tahap akhir koagulasi dengan membentuk bekuan fibrin. LF digunakan sebagai bahan hemostatis yang menghentikan pendarahan dari celah insisi, matriks untuk 
penyembuhan luka dan perekat jaringan (Spotnitz \& Prabhu, 2005).

Meskipun luas penggunaannya, LF yang didapat secara komersial relatif mahal, sehingga tidak ekonomis. LF komersial ini mengandung protein plasma yang dimurnikan dari sumber darah lain, yang beresiko terjadinya kontaminasi patogen secara bersamaan dengan perawatan. Untuk membuat LF, diperlukan sumber bahan yang lebih berlimpah dan lebih aman. Saat ini, trombin pada LF komersial biasanya terbuat dari plasma beku segar sapi (Enus dkk., 2011). LF komersial sebagai pengganti jahitan memberikan banyak keuntungan, yaitu operasi lebih nyaman, lebih cepat dan dapat terhindar kerugian akibat jahitan (Enus dkk., 2009; Yuksel et al., 2010). Sampai saat ini LF komersial untuk operasi mata belum tersedia di Indonesia, sehingga harus diimpor dengan harga yang sangat mahal dan perlu penyimpanan secara khusus. Permasalahan lain yang muncul adalah belum adanya izin khusus dari Food and Drug Administration untuk pemakaian LF komersial pada operasi mata, terkait transmisi penyakit karena terbuat dari plasma donor (Enus dkk., 2009).

Aplikasi teknologi rekombinan memungkinkan untuk memproduksi dan memasarkan protein plasma untuk aplikasi terapeutik manusia (Burnouf, 2011). Penggunaan teknologi rekombinan untuk trombin manusia rekombinan menggunakan E. coli telah dilakukan (Soejima et al., 2001). Pemilihan E. coli untuk produksi trombin manusia rekombinan karena sifatnya yang dapat tumbuh cepat dengan siklus hidup pendek, informasi dan karakter genomnya sudah lengkap sehingga mudah dimanipulasi, biaya produksi relatif murah, tingkat ekspresi protein target tinggi, cepat, dan teknologinya sudah mapan (Baneyx \& Mujacic, 2004; Cabrita et al., 2006).

Pemurnian protein menggunakan domain pengikat kitin yang dimediasi intein menjadi menarik untuk dikembangkan. Sistem IMPACT-TWIN (Intein Mediated Purification with an Affinity Chitin-binding Tag-Two Intein) merupakan vektor ekspresi sekaligus sebagai sistem pemurnian yang menggunakan induksi aktivitas pemecahan protein target dari penanda intein. Penanda intein ini dapat memungkinkan terjadinya proses pemisahan secara pemotongan diri sendiri (self-cleavage) dalam kolom kromatografi afinitas kitin.
Pelepasan protein target dari protein penanda intein dapat dilakukan dengan penambahan pereaksi tiol ( $\beta$-mercaptoetanol) pada $\mathrm{C}$ terminal (Li et al., 2012) dan atau buffer perubahan $\mathrm{pH}$ dan suhu pada N-terminal (Guo et al., 2004). Manfaat utama dari strategi pemurnian protein yang dimediasi oleh intein adalah menghasilkan protein target dalam jumlah banyak, penggabungan protein target dapat dilakukan di ujung $\mathrm{C}$ ataupun ujung $\mathrm{N}$ protein intein, dan protein target dapat diisolasi dengan atau tanpa tambahan residu asam amino metionin (Chong et al., 1998; Xu \& Evans, 2001). Penggunaan pemurnian dimediasi intein dilaporkan dapat memurnikan protein hingga tingkat kemurnian mencapai 95\% (Li et al., 2012; Guo et al., 2004; Wu et al., 2002; Sharma et al., 2006).

\section{METODE}

Galur, vektor, bahan kimia, media

Kloning dan peremajaan plasmid menggunakan E. coli TOP1OF' (Invitrogen, USA), inang ekspresi yang digunakan adalah E. coli BL21(DE3) ArcticExpress (didukung oleh Prof. Jiri Damborsky, Masaryk University, Brno, Czech Republic). Inang ditumbuhan dalam media luria bertani (LB) dengan komposisi (tripton 1\%, ekstrak ragi $0,5 \%$, dan natrium klorida 1\%) yang disuplemen dengan antibiotik tetrasiklin (100 $\mu \mathrm{g} / \mathrm{mL})$, dan ampisilin (100 $\mu \mathrm{g} / \mathrm{mL})$. Untuk media padat, komponen media LB ditambahkan dengan 2\% agar. Semua enzim restriksi dan T4-DNA ligase dibeli secara komersial dari (New Englands Biolabs, USA). Vektor ekspresi menggunakan pTWIN1 diperoleh dari NEB (NEB, USA). Gen pretrombin-2 manusia disintesis oleh GeneArt (Life Technologies, Jerman). Kit isolasi DNA (Roche Applied Science, USA), Kit fragmen ekstraksi gel (Geneaid, Taiwan). Isopropyl- $\beta$ - $d$-thiogalactoside (IPTG) dan $\beta$ mercaptoethanol (B-ME) diperoleh dari Sigma. Poliakrilamid dan Coomassie Brilliant Blue R250 (Biorad, Richmond, USA). Matriks kitin diperoleh dari NEB (New Englands, Biolabs, USA). Bahan kimia lainnya tersedia di laboratorium Biokimia, Departemen Kimia, Universitas Padjadjaran, dengan tingkat proanalysis (p.a.).

\section{Konstruksi dan optimasi kodon gen PT2}

Gen $P$ T2 sintetik didesain ke dalam vektor 
ekspresi pTWIN1 menggunakan dua sisi restriksi pada ujung 5' dan 3' berturut-turut XhoI dan BamHI. Urutan asam amino PT2 (308 aa) termuat dalam data GenBank Accession number: NM_oo0506.3. Asam amino $\quad P T 2$ selanjutnya dioptimasi menggunakan perangkat lunak OPTIMIZER (http://gnomes.urv.es/OPTIMIZER) (Puigbo et al., 2007) sesuai kodon preferensi $E$. coli yang termuat dalam Codon Usage Database (http://www.kazusa.or.jp/codon/). Kodon PT2 hasil optimasi kemudian dianalisis menggunakan Graphical Codon Usage Analyzer (GCUA) (http://gcua.schoedl.de/2 (Mclnerney, 1998).

\section{Kloning gen pretrombin-2}

Plasmid pMA-T-PT2 dipotong menggunakan enzim restriksi XhoI dan BamHI sesuai rancangan gen sintetik sebelumnya. Secara paralel, pTWIN1 dipotong dengan menggunakan enzim restriksi yang sama. Hasil pemotongan selanjutnya dikarakterisasi menggunakan elektroforesis gel agarose $1 \%$. Selanjutnya fragmen $P T 2$ dan pTWIN1 hasil pemotongan diekstraksi dari gel agarosa dan dikarakterisasi. Selanjutnya fragmen PT2 diligasi ke dalam vektor pTWIN1 menggunakan enzim T4 DNA ligase hingga diperoleh plasmid pTWIN1 yang mengandung sisipan PT2 (pTWIN1-PT2). Selanjutnya, dilakukan transformasi sel kompeten $E$. coli TOP1OF' dalam plasmid pTWIN1-PT2 dengan metode kejut panas (Sambrook \& Russell, 2001). Untuk mendapatkan plasmid pTWIN1$P T 2$, maka koloni transforman E. coli TOP1OF' diisolasi. Penentuan urutan nukleotida dengan DNA sequencer (MacroGene, Korea) dilakukan untuk memverifikasi keberhasilan kloning.

\section{Ekspresi protein fusi PT2 dalam E. coli}

Ekspresi dilakukan dengan menggunakan penginduksi IPTG di galur E. coli BL21(DE3 ArcticExpress Galur-galur ini merupakan $E$. coli dengan sistem promoter $\mathrm{T}_{7}$ yang sesuai dengan vektor pTWIN1. Koloni tunggal transforman $E$. coli ditumbuhkan dalam $5 \mathrm{~mL}$ media LB cair yang mengandung antibiotik sesuai, selanjutnya diinkubasi pada suhu $37^{\circ} \mathrm{C}$ selama 16 jam. Sebanyak $1 \mathrm{~mL}$ kultur dimasukkan ke dalam $100 \mathrm{~mL}$ LB cair yang ditambahkan antibiotik ampisilin (100 $\mu \mathrm{g} / \mathrm{mL}$ ) dan diinkubasi pada suhu $37{ }^{\circ} \mathrm{C}$

selama 3-4 jam dengan pengocokan $150 \mathrm{rpm}$ hingga $\mathrm{OD}_{60}$ 5-7. Sebanyak $1 \mathrm{~mL}$ kultur S.Silaban, dkk. diambil sebagai sampel sebelum induksi. Ke dalam kultur sisa, ditambahkan IPTG (100 $\mathrm{mg} / \mathrm{mL}$ ) dengan konsentrasi akhir 0,1 mM. Selanjutnya ditumbuhkan pada suhu $12{ }^{\circ} \mathrm{C}$ selama 16 jam. Sebanyak $1 \mathrm{~mL}$ kultur diambil sebagai sampel setelah induksi. Pelet dipanen dalam tabung Eppendorf $50 \mathrm{~mL}$ menggunakan sentrifugator pada suhu $4^{\circ} \mathrm{C}$, $7500 \mathrm{~g}$. Selanjutnya pelet disuspensi dengan $20 \mathrm{~mL}$ buffer lisis A (Tris- $\mathrm{HCl} 10 \mathrm{mM}, \mathrm{NaCl}$ $500 \mathrm{mM}$, PMSF $1 \mathrm{mM}$ pH 8.5, Triton X-100 1\%), kemudian dilisis menggunakan sonikator selama 15 menit dalam wadah dingin. Lisat kemudian disentrifugasi pada $7500 \mathrm{~g}$ selama 20 menit. Sebanyak $40 \mu \mathrm{L}$ supernatan diambil sebagai sampel protein larut. Pelet ditambahkan dengan $50 \mu \mathrm{L}$ urea $8 \mathrm{M}$, dipanaskan pada suhu $95{ }^{\circ} \mathrm{C}$ selama 15 menit dan disentrifugasi selama 10 menit, sebanyak $40 \mu \mathrm{L}$ supernatan diambil sebagai sampel protein tidak larut. Masing-masing sampel ditambahkan $5 \mu \mathrm{L}$ SDS-Dye, kemudian dipanaskan pada suhu $95{ }^{\circ} \mathrm{C}$ selama 15 menit dan disentrifugasi $7500 \mathrm{~g}$ selama 1 menit. Untuk memverifikasi ekspresi PT2 dan kelarutannya, sebanyak $10 \mu \mathrm{L}$ sampel dimuat dalam poliakrilamid gel $12,5 \%$. Pita protein divisualisasikan dengan pewarna Coomassie Brilliant Blue R250.

\section{Pemurnian protein fusi PT2 dimediasi intein}

Sebanyak $20 \mathrm{~mL}$ supernatan yang diperoleh dari 1 L kultur dimasukkan ke dalam $5 \mathrm{~mL}$ matriks kitin pada kolom, yang disetimbangkan sebelumnya dengan buffer B (Tris-HCl $10 \mathrm{mM}, \mathrm{NaCl} 500 \mathrm{mM} \mathrm{pH} \mathrm{8.5)} 4{ }^{\circ} \mathrm{C}$, 10 kali volume kolom. Supernatan ditampung sebagai sampel flowthrough untuk karakterisasi SDS-PAGE. Protein yang tidak diinginkan dicuci dengan buffer B sebanyak 20 kali volume kolom dan ditampung sebagai sampel pencuci untuk karakterisasi, selanjutnya resin diambil sebanyak $100 \mu \mathrm{L}$ sebagai sampel resin sebelum pemotongan. Sebanyak $15 \mathrm{~mL}$ buffer pemotong (Tris-HCl 10 $\mathrm{mM}, \mathrm{NaCl} 500 \mathrm{mM} \mathrm{pH}$ 6.5) dimasukkan ke dalam kolom, kemudian kolom diinkubasi pada suhu $25{ }^{\circ} \mathrm{C}$ selama 48 jam. Setelah inkubasi, kolom dielusi dengan buffer pemotong sebanyak $8 \mathrm{~mL}$ dan fraksi ditampung masing-masing $1 \mathrm{~mL}$ dalam tabung Eppendorf 1,5 mL. Resin diambil kembali sebanyak $100 \mu \mathrm{L}$ sebagai sampel setelah pemotongan. Semua sampel dan fraksi dikarakterisasi menggunakan SDS-PAGE 12.5\%. Mekanisme pemurnian PT2 267 
menggunakan pTWIN1 yang di fusikan pada C-terminal intein ditunjukkan pada Gambar 1.

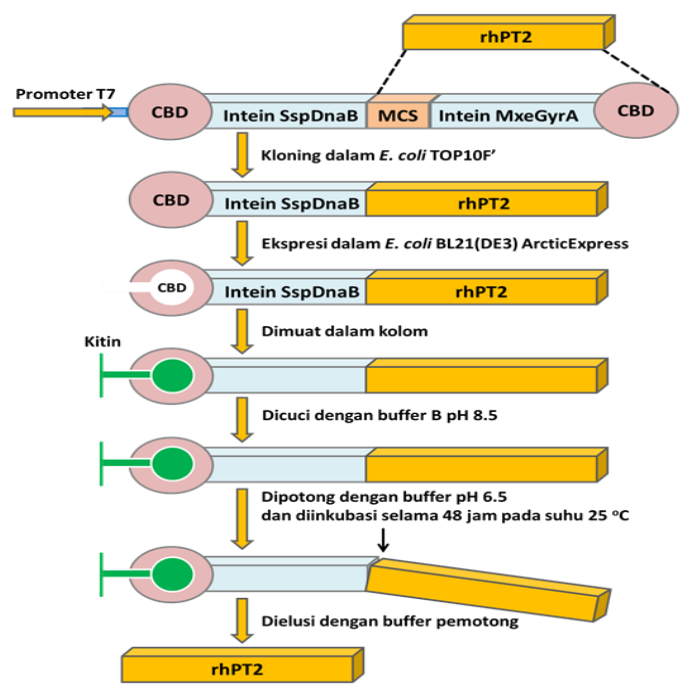

Gambar 1. Pemurnian PT2 dengan vektor pTWIN1. Penanda intein difusikan pada Nterminal PT2 dan pelepasan PT2 diinduksi pemotongan oleh $\mathrm{pH}$ dan suhu (dimodifikasi dari NEB).

\section{HASIL DAN PEMBAHASAN}

Optimasi, kloning dan ekspresi pretrombin-2 manusia dalam E. coli

Urutan asam amino PT2 dianalisis menggunakan perangkat lunak OPTIMIZER. Hasil analisis diperoleh bahwa urutan gen PT2 berukuran $924 \mathrm{pb}$, dengan persentase GC sebesar 52,56\% dan Codon Adaptation Index sebesar 0,89. Kodon PT2 tersebut selanjutnya dianalisis menggunakan Graphical Codon Usage Analyzer. Dari hasil analisis diperoleh 149 asam amino dikode oleh kodon-kodon yang tidak preferensi bagi $E$. coli (Silaban et al., 2015). Selanjutnya kodon-kodon PT2 yang tidak preferens, dioptimasi sesuai kodon preferensi $E$. coli dan dianalisis kembali dengan GCUA. Hasil analisis kodon PT2 sintetik teroptimasi diperoleh persentase GC 54,7\% dan CAI sebesar 1,00 (Silaban dkk., 2016).

Untuk mendapatkan fragmen $P T 2$, plasmid pMA-T-PT2 dipotong menggunakan enzim XhoI dan BamHI. Dengan enzim yang sama, pTWIN1 dipotong dan dikarakterisasi menggunakan elektroforesis gel agarose $1 \%$. Hasil karakterisasi gel menunjukkan bahwa fragmen PT2 berhasil dipotong dari pMA-T, dimana terdapat dua pita sebesar $939 \mathrm{pb}$ (PT2) dan 2374 pb (pMA-T). Demikian juga hasil karakterisasi pTWIN1 dalam gel, diperoleh dua pita sebesar 6536 pb (pTWIN1) dan $839 \mathrm{pb}$ (Multi Cloning Site) (Silaban et al., 2015; Silaban dkk., 2016). Fragmen PT2 dan pTWIN1 yang diperoleh, diekstrak dan dimurnikan menggunakan kit isolasi DNA. Hasil karakterisasi menunjukkan bahwa $P T 2$ dan pTWIN1 berhasil diekstrak dan dimurnikan dari gel. Terdapat dua pita $939 \mathrm{pb}$ (PT2) dan 6536 pb (pTWIN1) (Silaban et al., 2015; Silaban dkk., 2016). Selanjutnya fragmen PT2 diligasi ke dalam vektor pTWIN1 menggunakan enzim $\mathrm{T}_{4}$ DNA ligase. Untuk mengkonfirmasi keberhasilan proses ligasi, nukleotida pTWIN1-PT2 ditentukan oleh DNA sequencing. Hasil pensejajaran urutan nukleotida menunjukkan, PT2 berhasil terligasi ke vektor pTWIN1 (Silaban et al., 2015; Silaban dkk., 2016).

Pemilihan sistem ekspresi yang tepat sangat penting untuk produksi dalam jumlah besar protein yang larut dalam sel inang. Untuk mencapai hal ini, vektor ekspresi pTWIN1 telah digunakan. Vektor pTWIN1 dilaporkan telah berhasil digunakan untuk ekspresi protein rekombinan dengan hasil tinggi (Smith et al., 2012). Penggunaan vektor pTWIN1 dalam sistem ekspresi, karena kemampuannya untuk memproduksi protein larut dalam jumlah besar. Kemampuan ini disebabkan kekhususan promotor $\mathrm{T}_{7}$, yang hanya mengikat $\mathrm{T}_{7}$ RNA polimerase. Diperkirakan bahwa induksi transkripsi dalam sistem vektor $\mathrm{T}_{7}$ lebih besar dari 1000 kali lipat, sedangkan besarnya induksi yang diperoleh dengan promotor lac represor umumnya diatur sekitar 50 kali lipat. Sistem ekspresi $\mathrm{T}_{7}$ akan aktif dengan adanya enzim $\mathrm{T}_{7}$ RNA polimerase. $\mathrm{T}_{7}$ RNA polimerase tidak terdapat pada bakteri secara alami, namun $E$. coli ArcticExpress telah dirancang untuk membawa gen yang mengkode RNA polimerase pada segmen DNAnya. Induksi ekspresi fusi PT2 dilakukan dengan penambahan IPTG. IPTG merupakan substansi yang mencegah lac represor terikat pada lac operator sehingga menginduksi ekspresi gen untuk membentuk protein aktif. $\mathrm{Hal}$ ini mengawali pembentukan $\mathrm{T}_{7} \mathrm{RNA}$ polimerase dalam jumlah yang lebih substansial, karena $\mathrm{T}_{7} \mathrm{RNA}$ polimerase spesifik untuk promoter $\mathrm{T} 7$, maka gen $p t 2$ yang dikode di dalam plasmid tersebut akan mengalami over-ekspresi (Dubendorf \& Studier, 1991). 
Tabel 1. Ekspresi fusi PT2 di E. coli BL21(DE3) ArcticExpress.

\begin{tabular}{lcc}
\hline & \multicolumn{2}{c}{ Fusi CBD-Intein SspDnaB-PT2 } \\
\cline { 2 - 3 } & Larut & Tidak larut \\
\hline BL21(DE3) & +++++ & ++ \\
ArcticExpress & & \\
\hline
\end{tabular}

Perbedaan persentase kandungan GC antara gen target dengan inang ekspresi menyebabkan adanya bias kodon, dan selanjutnya bias kodon yang tinggi akan menurunkan tingkat ekspresi karena diperkirakan akan dapat menyebabkan kesalahan translasi (Merkl, 2003; Gustafsson et al., 2014), sehingga menghasilkan protein agregat kompleks tidak aktif yang lazim dikenal sebagai badan inklusi (Freydell et al., 2007). Nukleotida $P T 2$ sintetik, selain banyak memiliki kodon jarang juga kandungan GC nya tinggi, sehingga diperlukan optimasi kodon gen sesuai preferensi kodon $E$. coli melalui memanfaatkan teknologi gen sintetik. Pemanfaatan teknologi gen sintetik mampu mengubah bias kodon dari gen target menjadi cocok dengan kodon preferensi inang rekombinan (Graslund et al., 2008; Xiong et $a l ., 2008)$. Setiap gen dalam genom memiliki nilai numerik yang disebut indeks adaptasi kodon (Codon Adaptation Index,CAI). Beberapa peneliti melaporkan bahwa nilai CAI dapat digunakan untuk memprediksi tingkat ekspresi protein heterolog (Carbone et al., 2003; Xia, 2007; Fox \& Erill, 2010). Optimasi kodon gen $P T 2$ dapat meningkatkan nilai CAI PT2 sintetik menjadi 1,00 dan secara teori nilai CAI tersebut dianggap bagus untuk ekspresi (Carbone et al., 2003; Xia, 2007).

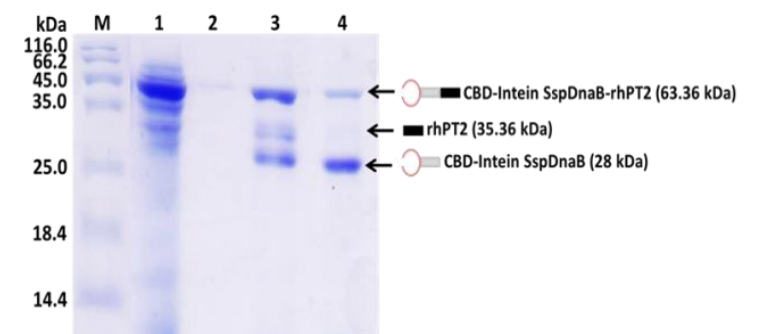

Gambar 2. Analisis SDS-PAGE 12,5\% hasil pemurnian protein fusi PT2 dimediasi intein. M: marker protein standar, lajur 1: flowthrough, lajur 2: buffer pencuci, lajur 3: resin kitin sebelum dipotong, dan lajur 4: resin kitin setelah dipotong menggunakan buffer $\mathrm{pH} 6.5$ dan inkubasi selama 48 jam pada suhu $25^{\circ} \mathrm{C}$.

Pembentukan badan inklusi selama produksi protein dalam inang prokariot juga dapat dicegah dengan mengurangi suhu selama ekspresi protein, karena suhu rendah biasanya meningkatkan kelarutan protein (Freydell et al., 2007). Namun, penurunan suhu dapat memperlambat pertumbuhan sel, sehingga tingkat sintesis protein lebih rendah. E. coli BL21(DE3) ArcticExpress merupakan inang yang direkayasa untuk mampu tumbuh pada suhu rendah. Inang ini mampu mengekspresikan Cpn6o/Cpn10 Oleispera antartica dari bakteri psikrofilik laut Antartika, sehingga kegiatan pelipatan tinggi dengan mengatur pertumbuhan $E$. coli pada suhu rendah $\left(4-12{ }^{\circ} \mathrm{C}\right)$ (Strocchi et al., 2006). Karakterisasi tes ekspresi menunjukkan bahwa sel-sel E. coli BL21(DE3) ArcticExpress mampu mengekspresikan fusi PT2 secara optimal dalam bentuk larut (Tabel 1). Perolehan fusi PT2 larut pada inang ini disebabkan bekerjanya Cpn6o/Cpn10 dalam membantu pelipatan protein fusi PT2 (Ferrer et al., 2003; Ferrer et al., 2004).

\section{Pemurnian PT2 dïnduksi perubahan $p H$ dan suhu}

Fusi PT2 dimurnikan dalam kolom matriks kitin dimediasi intein. Supernatan dimasukkan ke dalam kolom matriks kitin yang telah disetimbangkan sebelumnya dengan buffer B pH 8.5 (lajur 1 Gambar 2). Selanjutnya kolom dicuci dengan buffer B. Hasil karakterisasi SDS-PAGE menunjukkan bahwa setelah kolom dicuci dengan buffer B untuk menghilangkan protein-protein lain yang tidak spesifik, tidak ada protein fusi intein-CBD yang terlihat (lajur 2). Hasil ini menunjukkan bahwa protein fusi terikat pada resin kitin karena adanya aktivitas pengikatan yang tinggi dari domain pengikat kitin yang terletak pada intein terhadap resin (Li et al., 2012). Setelah dicuci, selanjutnya pemecahan diri PT2 yang dimediasi intein diinduksi dengan penambahan agen pemecah $\beta$ merkaptoetanol. Protein PT2 dipisahkan dari kitin dan dielusi dengan buffer pemecah. Efisiensi pemecahan dapat terlihat dengan membandingkan matriks kitin sebelum pemecahan (lajur 3) dan setelah pemecahan (lajur 4). Penambahan agen pemecah dan inkubasi selama 48 jam pada suhu $25{ }^{\circ} \mathrm{C}$ menyebabkan pita fusi CBD-Intein SspDnaBPT2 berkurang (lajur 4), artinya protein PT2 telah terpotong sebagian dari fusi CBD-Intein SspDnaB. Penanda intein mampu melakukan proses pemotongan diri sendiri (self-cleavage) dengan mengubah $\mathrm{pH}$ dan suhu indusi dalam kolom kromatografi afinitas kitin pada Cterminal intein (Guo et al., 2004). 


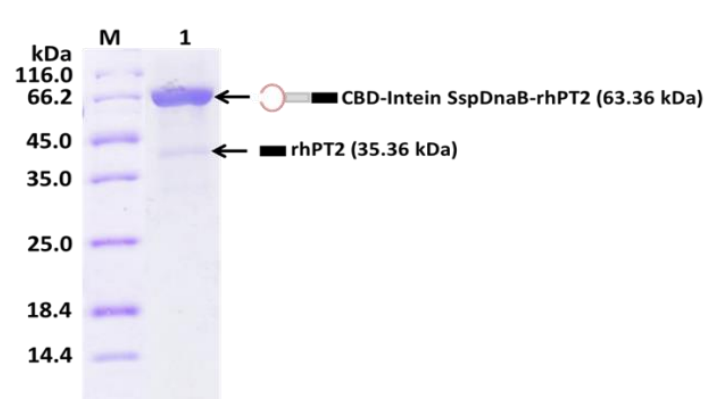

Gambar 3. Analisis SDS-PAGE 12,5\% fraksi protein fusi PT2 hasil pemotongan. M: marker protein standar, lajur 1: fraksi PT2 hasil elusi setelah dipotong dengan $\mathrm{pH} 6.5$ dan inkubasi selama 48 jam pada suhu $25^{\circ} \mathrm{C}$.

Pemotongan fusi PT2 dipisahkan dari kitin menggunakan pengelusi buffer pemotong. Karakterisasi dengan SDS-PAGE menunjukkan bahwa matriks kitin sebelum pemotongan terdapat tiga pita yang terdeteksi yaitu pita berukuran 35,36 kDa (lajur 3), 28 $\mathrm{kDa}$ (lajur 3) dan 63,36 kDa (lajur 3). Setelah pemotongan dengan buffer pemotong (lajur 4), pada matriks kitin hanya dua pita yang terdeteksi yaitu pita berukuran $35,36 \mathrm{kDa}$ (lajur 4) dan pita berukuran 63,36 kDa (lajur 4). Adanya perbedaan pola pita protein dari sampel matriks kitin sebelum dan setelah pemotongan mengindikasikan bahwa sebagian fusi PT2 (35,36 kDa) telah terlepas dari fusi CBD-intein SspDnaB. Gambar 3 menunjukkan bahwa telah diperoleh protein PT2 murni dalam jumlah kecil. Hanya saja, PT2 belum terpisah sempurna, sehingga optimasi pemotongan PT2 sampai saat ini masih terus dilakukan. Pemurnian protein yang dimediasi intein menggunakan penginduksi $\mathrm{pH}$ dan suhu pada posisi Cterminal intein sangat sensitif terhadap $\mathrm{pH}$ buffer (Setrerrahmane et al., 2014; Zhang et al., 2015). Buffer dengan kondisi $\mathrm{pH}$ yang tidak sesuai menyebabkan pemotongan protein dari fusi intein tidak akan maksimal.

\section{KESIMPULAN}

Dalam studi ini, kami mengoptimalkan ekspresi PT2 dalam E. coli. Protokol dioptimalkan, termasuk penggunaan: (i) penggunaan kodon gen $P T 2$ yang cocok dengan kodon inang $E$. coli, (ii) vektor ekspresi dengan promotor $\mathrm{T}_{7}$ yang kuat, dan (iii) galur E. coli yang mampu tumbuh dengan penurunan suhu. Protokol ini menghasilkan PT2 larut. Pemurnian dalam kolom matriks kitin yang dimediasi intein dapat memurnikan PT2, dan PT2 dapat dipotong dari intein-tag menggunakan buffer pemecah $\mathrm{pH} 6.5$ dan inkubasi selama 48 jam pada suhu $25{ }^{\circ} \mathrm{C}$.

\section{DAFTAR PUSTAKA}

Baneyx, F., \& Mujacic, M. (2004). Recombinant protein folding and misfolding ini Escherichia coli. Nat Biotechnol, 22:1399-1408.

Burnouf, T. (2011). Recombinant plasma proteins. Vox Sanguinis, 100:8-83.

Cabrita, L.D., Weiwen, D., \& Stephen, P.B. (2006). A family of E.coli expression vectors for laboratory scale and high throughput soluble protein production. BMC Biotechno, 6:12.

Carbone, A., Zinovyev, A., \& Kepes, F. (2003). Codon adaptation index as a measure of dominating codon bias. Bioinformatics, 19:2005-2015.

Chong, S., Montello, G.E., Zhang, A., Cantor, E.J., Liao, W., Xu, M.Q., \& Benner, J. (1998). Utilizing the C-terminal cleavage activity of a protein splicing element to purify recombinant proteins in a single chromatographic step. Nucl. Acids Res, 26:5109-5115.

Dubendorff, J.W., \& Studier, F.W. (1991). Controlling basal expression in an inducible $\mathrm{T}_{7}$ expression system by blocking the target $\mathrm{T} 7$ promoter with lac repressor. J. Mol. Biol, 219:45-59.

Enus, S., Dalimoenthe, N.Z., \& Kartiwa, A. (2009). Teknik lem fibrin otologus pada cangkok konjungtiva bulbi mata Kelinci. $M K B$, 41:169-173.

Enus, S., Natadisastra, G., Shahib, M.N., \& Sulaiman, R. (2011). Peran lem fibrin otologus pada penempelan tandur konjungtiva bulbi mata kelinci terhadap ekspresi gen fibronektin dan integrin. $M K B, 43: 183-188$.

Ferrer, M., Chernikova, T.N., Yakimov, M.M., Golyshin, P.N., \& Timmis, K.N. (2003). Chaperoneins govern growth of Escherichia coli at low temperatures. Nature. Biotechnology, 21:1266-1267.

Ferrer, M., Chernikova, T.N., Timmis, K.N., \& Golyshin, P.N. (2004). Expression of a temperature-sensitive esterase in a novel chaperonee-based Escherichia coli strain. APPL. Environ. Microbiol, 70:44994504.

Fox, J.M., \& Erill, I. (2010). Relative codon adaptation: a generic codon bias index for 
prediction of gene expression. DNA Research, 17:185-196.

Freydell, E.J., Ottens, M., Eppink, M., van Dedam, G., \& van der Wielen, L. (2007). Efficient solubilization of inclusion bodies. Biotechnol J, 2:678-684.

Graslund, S., Nordlund, P., Weigelt, J., Hallberg, B.M., Bray, J., Gileadi, O et al. (2008). Protein production and purification. Nature Method, 5:135-156.

Gustafsson, C., Govindrajan, S., \& Minshull, J. (2004). Codon bias and heterologous protein expression. Trends in Biotechnol, 22:346-353.

Guo, C., Lia, Z., Shia, Y., Xub, M., Wisec, J.G., Trommerc, W.E., \& Yuan, J. (2004). Intein-mediated fusion expression, high efficient refolding,and one-step purification of gelonin toxin. Protein Expression and Purification, 37:361-367.

Li, J., Zheng, L., Li, P., \& Wang, F. (2012). Intein-mediated expression, purification, and characterization of thymosin $\alpha 1-$ thymopentin fusion peptida in Escherichia coli. Protein Expression and Purification, 84:1-8.

Mclnerney, J.O. (1998). GCUA: General Codon Usage Analysis. Bioinformatics Applications Note. Oxford University Press, 14:372-373.

Merkl, R. (2003). A survey of codon and amino acid frequency bias in microbial genomes focusing on translational efficiency. J. Mol. Evol, 57:453-466.

Puigbo, P., Guzma, E., Romeu, A., \& Vallve, S.G. (2007). OPTIMIZER: a web server for optimizing the codon usage of DNA sequences. Nucleic. Acids. Research, W126-W131.

Sambrook, J., \& Russel, D.W. (2001). Molecular cloning: A laboratory manual. $3^{\text {nd }}$ Edn. CSHL Press, USA.

Setrerrahmane, S., Zhang, Y., Dai, G., Lv, J and Tan, S. (2014). Efficient Production of Native Lunasin with Correct N-terminal Processing by Using the pH-InducedSelfCleavable Ssp DnaB Mini-intein System in Escherichia coli. Appl. Biochem. Biotechnol, 174:612-622.

Sharma, S.S., Chong, S., \& Harcum, S.W. (2006). Intein-mediated protein purification of fusion proteins expressed under high-cell density conditions in $E$. coli. Journal of Biotechnology, 125:4856.
Silaban, S., Maksum, I.P., Ghaffar, S., Hasan, K., Enus, S., Subroto, T., \& Soemitro, S. (2015). Codon Optimization and Chaperone Assisted Solubilization of Recombinant Human Prethrombin-2 Expressed in Escherichia coli. Microbiology Indonesia, 8(4):177.

Silaban, S., Maksum, I.P., Enus, S., Hasan, K., Subroto, T., \& Soemitro, S. (2016). Kajian Ekspresi Gen Pretrombin-2 Manusia Sintetik pada Escherichia coli Secara In Silico untuk Produksi Trombin Sebagai Komponen Lem Fibrin. Jurnal Pendidikan Kimia, 8(1):58-64.

Smith, L.E., Yang, J., Goodman, L., Huang, X., Huang, R., Dressman, J., Morris, J., Silva, R.A.G.D., Davidson, W.S \& Cavigiolio, G. (2012). High yield expression and purification of recombinanthuman apolipoprotein A-II in Escherichia coli. $J$. Lipid. Res, 53:1708-1715.

Soejima, K., Mimura, N., Yonemura, H., Nakatake, H., T. Imamura, T., \& Nozaki, C. (2001). An efficient refolding method for the preparation of recombinant human prethrombin-2 and characterization of the recombinantderived a-thrombin. J. Biochem, 130:269-277.

Spotnitz, W.D. (2001). Commercial fibrin sealants in surgical care. Am $J$ Surg, 182:8S-14.

Strocchi, M., Ferrer, M., Timmis, K.N., \& Golyshin, P.N. (2006). Low temperatureinduced systems failure in Escherichia coli: Insights from rescue by cold-adapted chaperoneines. Proteomics, 6:193-206.

Uy, H.S., Reyes, J.M., Flores, J.D., \& Siong, R.L.B. (2005). Comparison of fibrin glue and sutures for attaching conjungtival autografts after pterygium excision. Ophthalmology, 112:667-671.

Wu, W., Wood, D.W., Belfort, G., Derbyshire, V., \& Belfort, M. (2002) Intein-mediated purification of cytotoxic endonuclease ITevI by insertional inactivation and $\mathrm{pH}-$ controllable splicing. Nucleic Acids Research, 30:4864-4871.

Xia, X. (2007). An improved implementation of codon adaptation index. Evolutionary Bioinformatics, 3:53-58.

Xiong, A.S., Peng, R.H., Zhuang, J., Gao, F., Li, Y., Cheng, Z.M., \& Yao, Q.H. (2008). Chemical gene synthesis: strategies, softwares, error corrections, and 
applications. FEMS.Microbiol, 32:522540.

$\mathrm{Xu}$, M.Q., \& Evans, J.T.C. (2001). Inteinmediated ligation and cyclization of expressed proteins, METHODS. 24:257277.

Yuksel, B., Unsal, S.K., \& Onat, S. (2010). Comparison of fibrin glue and suture technique in pterygium surgery performed with limbal autograft. Int. $J$. Ophthalmol, 3:316-320.

Zhang, Y., Zhang, K., Wan, Y., Zi, J., Wang, Y., \& Wang, J. (2015). A pH-Induced, InteinMediated Expression and Purification of Recombinant Human Epidermal Growth Factor in Escherichia coli. Biotechnol, Prog, 000:000-000. 